\title{
High Protein Diet that Cause Weight Loss and Lower Blood Glucose Level Have a Serious Impact on the Kidney Functions of Male Diabetic Obese Albino Rats
}

\author{
Ahmed El-Sayed Nour El-Deen ${ }^{1}{ }^{*}$, Abd El-Megeed Mansour ${ }^{1}$, Ahmad Taha² \\ ${ }^{1}$ Department of Physiology, Faculty of Medicine, Al-Azhar University, Assuit, Egypt \\ ${ }^{2}$ Department of Physiology, Faculty of Medicine, Port Said University, Port Said, Egypt \\ Email:*drnoor83@hotmail.com
}

How to cite this paper: Nour El-Deen, A.E.-S., Mansour, A.E.-M. and Taha, A. (2018) High Protein Diet that Cause Weight Loss and Lower Blood Glucose Level Have a Serious Impact on the Kidney Functions of Male Diabetic Obese Albino Rats. Food and Nutrition Sciences, 9, 1174-1191.

https://doi.org/10.4236/fns.2018.910085

Received: September 13, 2018

Accepted: October 15, 2018

Published: October 18, 2018

Copyright $(9) 2018$ by authors and Scientific Research Publishing Inc. This work is licensed under the Creative Commons Attribution International License (CC BY 4.0).

http://creativecommons.org/licenses/by/4.0/

\section{(c) (i) Open Access}

\begin{abstract}
Background: High protein (HP) diets are increasingly being recommended as one of the management strategies for weight control in overweight and obese individuals. The health benefits of high protein diets are well-established, but the mechanisms of action on body systems responsible for the changes in body weight and glycaemic control are not well-clear. Objective: The present study aimed to examine the effect of HP diets on the kidney functions of diabetic obese albino rats. Material and Methods: Eighty male adult male albino rats were used in this study. The animals were divided into eight equal groups (10 rats for each). Type $2 \mathrm{DM}$ and obesity were induced. At the end of the 12 weeks, samples were collected for biochemical analysis. Results: The high protein diet led to significant decrease in BW, FI, BG, TC, LDL, TG, Lactate dehydrogenase, albumin, urine $\mathrm{pH}$ and urine citrate; while serum insulin, HDL, urea, creatinine, total protein, urine volume and urinary excretion of $\mathrm{Ca}$ were significantly higher in high protein diet groups. Conclusion: A high protein intake in diabetic obese albino rats for 12 weeks led to changes in the serum and urine levels of markers of renal function which indicated abnormalities in the functions of the kidney.
\end{abstract}

\section{Keywords}

Obesity, Diabetes, High Protein Diet, Kidney Functions

\section{Introduction}

According to the World Health Organization, the prevalence of obesity world- 
wide has nearly has nearly tripled since 1975 [1]. Despite the high rates of morbidity and mortality caused by this epidemic, safe and effective obesity treatments remain elusive [2]. The use of high-protein (HP) diets is gaining in popularity among the general population [3]. Indeed, HP diets are increasingly being recommended as one of the management strategies for weight control in overweight and obese individuals [1]. Human research has demonstrated that high protein diets lead to weight loss, which may be due to an increased dietary thermogenesis, increased satiety and a decreased subsequent energy intake [4]. Additionally, a high-protein diet has been shown to conserve fat-free mass and to contribute to fat mass loss [5]. The health benefits of high protein diets are well-established [4] [6] [7] [8] [9] [10] but the mechanisms of action that are responsible for these changes in body are still unclear [11]. There is a scientific controversy on the effects of long-term consumption of these diets, and it has recently been reported that high protein intake is related with a higher risk of weight gain and with increased risk of fatal and non-fatal outcomes [12]. Although there are many human and animal studies focused on the physiological, biochemical and/or pathological effects induced by specific nutrients and dietary factors, there have been relatively few studies investigating safety and potential adverse effects of HP diets but diets with high protein content are generally considered safe and healthy in subjects without any pathology [5].

Because $90 \%$ of people with type 2 Diabetes Meletus (DM) are obese [4]. It is important to understand the effects of high levels of protein intake on health of diabetic individuals.

The present study aimed to examine the effect of HP diets on the kidney functions of diabetic obese albino rats.

\section{Material and Methods}

\subsection{Animals}

Eighty male adult male albino rats (8 weeks of age) of a local strain, weighing from 150 to $200 \mathrm{~g}$ used in this study were obtained from The Nile Co. For Pharmaceuticals and Chemical Industries (Cairo), and kept in suitable tainless-steel cages $(20 \times 32 \times 20 \mathrm{~cm}$ for every 3 rats $)$ at room temperature, with the natural light/dark cycle in the animal laboratory of Physiology Department, Al-Azhar Faculty of Medicine (Assiut). They were fed on the standard food prepared from commercial rat food formula (El-Nasr-Pharmaceutical Co.) in addition to bread and green vegetables, with free water supply. They were kept for ten days to adapt to the new conditions before starting the experiment.

The animals were divided into eight equal groups:

1) Normal control received normal protein diet.

2) Normal received high protein diet.

3) Obese received normal protein diet.

4) Obese received high protein diet.

5) Diabetic control received normal protein diet 
6) Diabetic received high protein diet.

7) Diabetic obese received normal protein diet.

8) Diabetic obese received high protein diet.

\subsection{Chemicals}

1) Blood glucose (BG) kit (Egyptian Company for Biotechnology-Egypt) [13].

2) Insulin kit (Sigma-Aldrich Co. LLC-USA) [14].

3) Serum cholesterol kit (Egyptian company for biotechnology-Egypt) [15].

4) Serum triglycerides kit (Egyptian Company for Biotechnology-Egypt) [16].

5) Serum high density lipoprotein (HDL) kit (Egyptian Company for Biotechnology-Egypt) [16].

6) Serum urea kit (Egyptian Company for Biotechnology [17].

7) Serum creatinine kit (Biolabo reagents kits - France) [18].

8) Urine Cacontent was determined by using a PerkinElmer Analyst 300 spectrophotometer (PerkinElmer, Wellesley, MA, USA) [19].

9) Urinary $\mathrm{pH}$ was analysed with a bench $\mathrm{pH}$-meter (Crison, Barcelona, Spain) [20].

10) Urinary citrate with a commercial kit (Spinreact, S.A. Gerona, España) [20].

11) Total proteins (TP), albumin and lactate dehydrogenase were measured with a Hitachi-Roche p 800 autoanalyzer [20].

12) Urine collection using clear plastic wrap [21].

\subsection{Induction of Diabetes}

Type 2 DM was experimentally induced by feeding a high fat diet (HFD) for an initial period of 2 weeks followed by an intraperitoneal injection of $35 \mathrm{mg} / \mathrm{kg}$ bwt streptozotocin dissolved in citrate buffer $\mathrm{pH} 4.5$ [22]. After injection of streptozotocin, the rats were kept for next 48 hours on oral $10 \%$ glucose solution on top of their chew. Administration of glucose was to prevent hypoglycaemia as STZ is capable of producing fatal hypoglycaemia due to destruction of $\beta$ cells which in turn results in to massive pancreatic insulin release [23].

Seven days after the injection, rats were screened for serum glucose levels in blood samples taken from tail, using Accu-Chek glucometer (Roche, Germany). Rats having serum glucose $\geq 200 \mathrm{mg} / \mathrm{dl}$, after 2 hours of glucose intake, were considered diabetic [22].

Induction of obesity was by feeding a high fat diet (HFD) (45\% energy from fat) and glucose in water for a period of 2 weeks [24]. Obesity was diagnosed by using body mass index $(\mathrm{BMI})=1 / 4$ body weight $(\mathrm{g}) /$ length ${ }^{2}\left(\mathrm{~cm}^{2}\right)[25]$.

\subsection{Experimental Diet}

A $45 \%$ high protein diet was formed as in (Table 1) to meet the nutritional requirements of adult rats as recommended by the American Institute of Nutrition (AIN-93M). [19] [26]. 
Table 1. Nutritional composition of the experimental diets.

\begin{tabular}{ccc}
\hline Nutritional Composition (g/100 g BW) & Normal-protein diet & high-protein diet \\
\hline Soy protein supplement & 13.1 & 57.4 \\
Mineral mix (AIN-93M-MX) & 3.5 & 3.5 \\
Vitamin mix (AIN-93-VX) & 1 & 1 \\
Fat (olive oil) & 4 & 4 \\
Choline chloride & 0.25 & 0.25 \\
Cellulose & 5 & 5 \\
Starch & 62.4 & 28.6 \\
Methionine & 0.5 & - \\
Sucrose & 10 & - \\
\hline
\end{tabular}

Body weight (BW) was measured weekly for all animals and the amount of food intake (FI) rat were registered daily.

At the end of $6^{\text {th }}, 9^{\text {th }}, 12^{\text {th }}$ weeks, a 12 -hour urine samples were collected and urine volumes (UV) were recorded, samples were transferred into graduated centrifuge tubes for measurement of $\mathrm{pH}, \mathrm{Ca}$, and citrate.

At the end of the $12^{\text {th }}$ week, food was withdrawn from the rats and they were fasted for $8 \mathrm{~h}$, but had free access to water, and then anesthetized with $\mathrm{CO}_{2}$. Blood specimens were collected from orbital venous plexus in non-heparinized tubes. Blood specimens were centrifuged at $2500 \mathrm{rpm}$ for $15 \mathrm{~min}$, and the clear samples of blood serum were separated and stored at $-80^{\circ} \mathrm{C}$ until used for the determination of the levelsof blood glucose (BG) level $(\mathrm{mg} / \mathrm{dl})$, insulin level (pmol/L), total cholesterol (TC) (mg/dl), LDL-cholesterol (mg/dl), HDL-cholesterol $(\mathrm{mg} / \mathrm{dl})$, triglycerides $(\mathrm{TG})(\mathrm{mg} / \mathrm{dl})$, urea $(\mathrm{mg} / \mathrm{dl})$, creatinine $(\mathrm{mg} / \mathrm{dl})$, total proteins $(\mathrm{g} / \mathrm{dl})$, albumin $(\mathrm{mg} / \mathrm{dl})$, and lactate dehydrogenase $(\mathrm{u} / \mathrm{L})$.

\subsection{Statistical Analysis}

The obtained data were subjected to analysis of variance according to the procedures out lined by Snedecor and Cochran. The mean values were compared according to Duncan's multiple range test (DMRT) [27]. The data were analysed using CoStat software for windows (version 6.3), (CoHort Software, Monterey, Calif).

\section{Results}

There were significant decreases in BW and FI $(\mathrm{p} \geq 0.01)$ between HP diet groups. The BG was significantly lower and insulin was significantly higher in high protein diet groups ( $(\mathrm{p} \geq 0.01)$ when we compared the (G1 and G2), (G2 and G4), (G5 and G6) and (G7 and G8). There is also significant increase in insulin level in obese groups when compared with non-obese rats (Table 2).

Means followed by a common letter are not significantly different at the $1 \%$ level by DMRT. Where G1: Normal control received normal protein diet; G2: Normal received high protein diet; G3: Obese received normal protein diet; G4: 
Table 2. (Means \pm Standard deviations (SD)) of body weight, food intake, blood glucose and insulin for all groups.

\begin{tabular}{ccccc}
\hline Groups & BW $(\mathrm{mg})$ & FI $(\mathrm{gm})$ & BG $(\mathrm{mg} / \mathrm{dl})$ & Insulin $(\mathrm{ng} / \mathrm{dl})$ \\
\hline G1 & $320.8 \mathrm{~d} \pm 4.4$ & $14.84 \mathrm{~d} \pm 1.2$ & $107 \mathrm{f} \pm 4.2$ & $32.8 \mathrm{~d} \pm 2.3$ \\
G2 & $232.6 \mathrm{f} \pm 15.5$ & $13.62 \mathrm{e} \pm 1.0$ & $75.2 \mathrm{~g} \pm 6.9$ & $38.6 \mathrm{c} \pm 1.4$ \\
G3 & $509.6 \mathrm{a} \pm 16.8$ & $20.04 \mathrm{~b} \pm 1.5$ & $120.3 \mathrm{e} \pm 4.0$ & $43.4 \mathrm{~b} \pm 1.6$ \\
G4 & $351.8 \mathrm{c} \pm 13.7$ & $15.72 \mathrm{~d} \pm 0.7$ & $81.3 \mathrm{~g} \pm 7.1$ & $47.9 \mathrm{a} \pm 1.3$ \\
G5 & $272.3 \mathrm{e} \pm 14.9$ & $23.45 \mathrm{a} \pm 1.7$ & $359.6 \mathrm{~b} \pm 27.0$ & $6.03 \mathrm{~h} \pm 0.8$ \\
G6 & $204.3 \mathrm{~g} \pm 4.6$ & $20.1 \mathrm{~b} \pm 0.8$ & $223.6 \mathrm{~d} \pm 16.7$ & $15.8 \mathrm{~g} \pm 1.2$ \\
G7 & $507.6 \mathrm{a} \pm 14.0$ & $19.78 \mathrm{~b} \pm 1.2$ & $447.4 \mathrm{a} \pm 21.6$ & $20.41 \mathrm{f} \pm 1.2$ \\
G8 & $385.7 \mathrm{~b} \pm 12.1$ & $17.74 \mathrm{c} \pm 1.0$ & $270.5 \mathrm{c} \pm 11.4$ & $24.97 \mathrm{e} \pm 1.1$ \\
P. & $0.00^{* *}$ & $0.00^{* *}$ & $0.00^{* *}$ & $0.00^{* *}$ \\
\hline
\end{tabular}

${ }^{*}$ indicate $\mathrm{P}<0.01$. Means followed by a common letter are not significantly different at the $1 \%$ level by DMRT.

Obese received high protein diet; G5: Diabetic control received normal protein diet; G6: Diabetic received high protein diet; G7: Diabetic Obese received normal protein diet; G8: Diabetic obese received high protein diet.

Data in Figure 1 showed that maximum reduction percent of BW for diabetic control rat's groups (15.12\%), BW was increased relative to normal control by (58.85\%). FI and BG was maximally increased in diabetic obese rats by $(58.2 \%)$ and $(318.3 \%)$ respectively, Maximum reduction in insulin level in diabetic control group by (-81.6\%) compare to normal control group (Figure 2 ).

As shown in Figure 2, BW were increased at least $51.25 \%$ and $65.82 \%$, of control received high protein diet in obese and diabetic obese groups, respectively. The diabetic control received high protein diet treatment decreased BW by $12.17 \%$ compare to normal control group.

\subsection{Effect of High Protein Diet on Lipid Profile (Table 3)}

Total cholesterol $(\mathrm{TC})$ was significantly $(\mathrm{P}<0.01)$ affected by protein diet treatments and was significantly decreased in G2, G4, G6, and G8 when compared with G1, G3, G5 and G7 respectively, G2 gave the lowest value ( $56.3 \mathrm{mg} / \mathrm{dl})$. LDL was significantly affected by protein diet and varied from 22.7 to 92 (Table 2) the highest value of LDL was recorded in G7, there was insignificant difference in LDL between G1 and G 6. There was significant increase in (HDL) by high protein diet in G2, G4, G6 and G8 when compared with G1, G3, G5 and G7 respectively, TG level was significantly decreased by protein diet treatment in G2, G4, G6, and G8 when compared with G1, G3, G5 and G7 respectively.

Data in Figure 3 showed that TC was increased in diabetic obese rat received normal diet relative to normal control by $(246.57 \%)$. LDL and TG were maximally increased in diabetic obese rats by $(111.49 \%)$ and (69.6\%) respectively, 

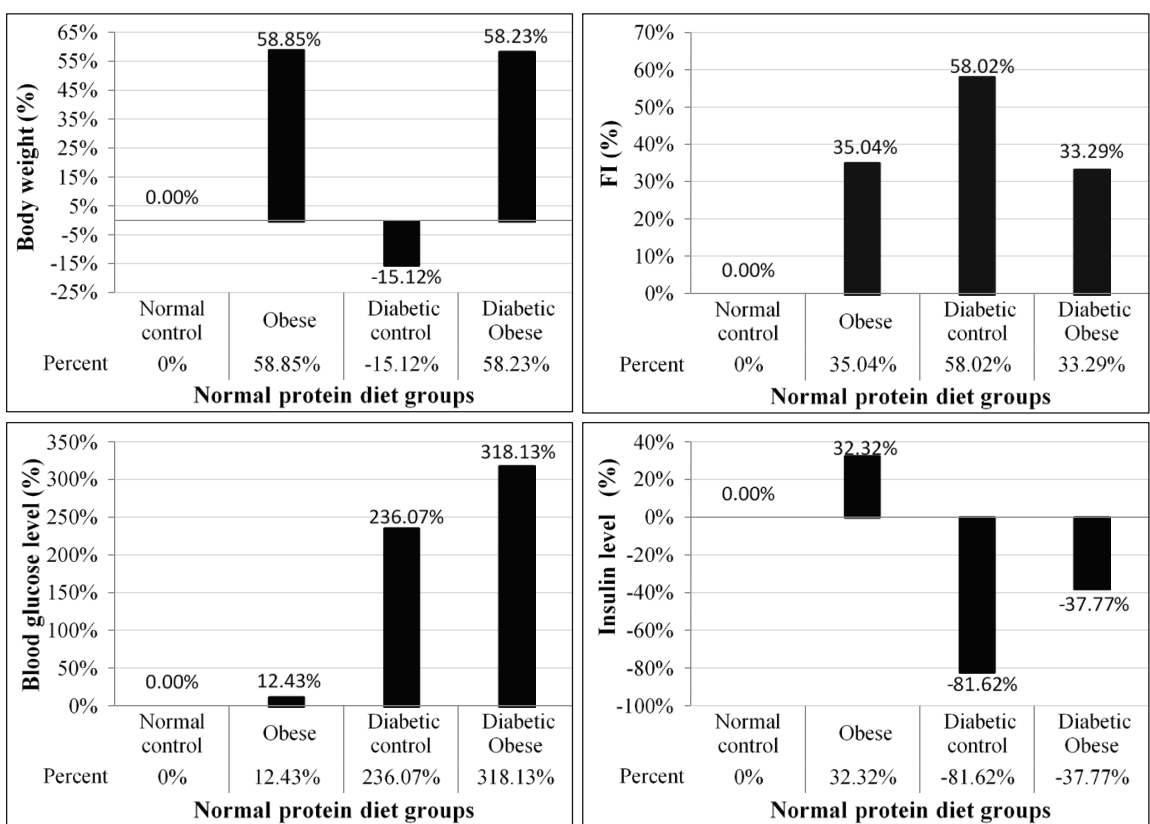

Figure 1. Percentage of body weight, FI, blood glucose level and insulin level for different groups received normal protein diet compare to normal control.
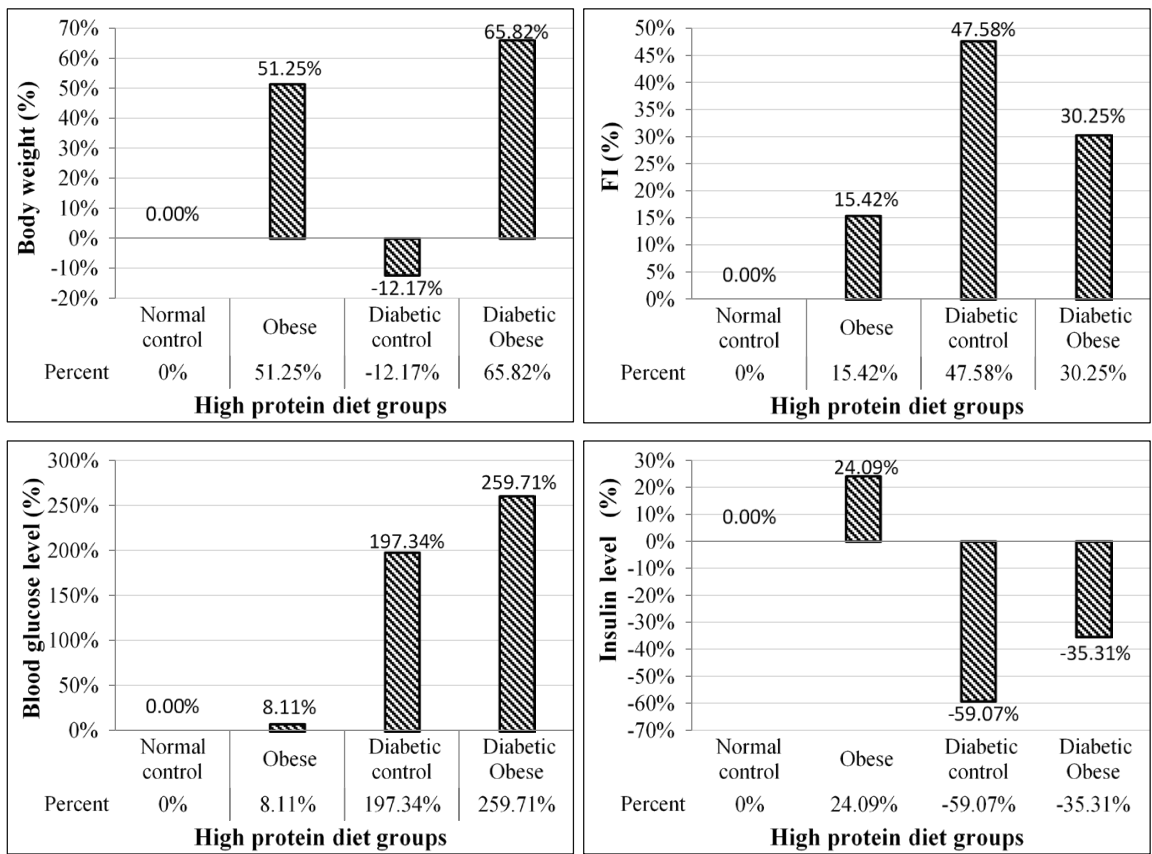

Figure 2. Percentage of body weight, FI, blood glucose level and insulin level for different groups received high protein diet compare to normal control.

Maximum reduction in HDL level in diabetic obese group by (-58.2\%) compare to normal control group.

Data in Figure 4 showed that TC was increased in diabetic obese rat received HP diet relative to normal control by (245.7\%). LDL and TG were maximally increased in diabetic obese rats by (129.9\%) and (120.8\%) respectively, 
Table 3. Means \pm (SD) of total cholesterol, low density lipoprotein, high density lipoproteinand triglyceride for all groups.

\begin{tabular}{ccccc}
\hline Groups & TC $(\mathrm{mg} / \mathrm{dl})$ & LDL $(\mathrm{mg} / \mathrm{dl})$ & HDL $(\mathrm{mg} / \mathrm{dl})$ & TG $(\mathrm{mg} / \mathrm{dl})$ \\
\hline G1 & $78.8 \mathrm{~g} \pm 4.3$ & $43.5 \mathrm{e} \pm 2.5$ & $42.4 \mathrm{~b} \pm 4.1$ & $93.2 \mathrm{e} \pm 5.7$ \\
G2 & $56.3 \mathrm{~h} \pm 4.6$ & $22.7 \mathrm{~g} \pm 1.9$ & $64.1 \mathrm{a} \pm 3.2$ & $55.3 \mathrm{f} \pm 6.4$ \\
G3 & $222.3 \mathrm{~b} \pm 8.2$ & $65 \mathrm{c} \pm 4.0$ & $30.4 \mathrm{~cd} \pm 2.1$ & $132.9 \mathrm{~b} \pm 7.8$ \\
G4 & $125.9 \mathrm{e} \pm 11.2$ & $34.4 \mathrm{f} \pm 3.6$ & $41.1 \mathrm{~b} \pm 2.6$ & $111.1 \mathrm{~d} \pm 7.5$ \\
G5 & $152.4 \mathrm{~d} \pm 8.8$ & $79.1 \mathrm{~b} \pm 4.8$ & $18.4 \mathrm{e} \pm 2.7$ & $131.7 \mathrm{~b} \pm 7.8$ \\
G6 & $107.2 \mathrm{f} \pm 4.1$ & $44.1 \mathrm{e} \pm 5.5$ & $32 \mathrm{c} \pm 3.7$ & $106.3 \mathrm{~d} \pm 5.2$ \\
G7 & $273.1 \mathrm{a} \pm 13.5$ & $92 \mathrm{a} \pm 4.0$ & $17.7 \mathrm{e} \pm 3.1$ & $158.1 \mathrm{a} \pm 8.5$ \\
G8 & $199.7 \mathrm{c} \pm 9.8$ & $52.2 \mathrm{~d} \pm 6.7$ & $29.1 \mathrm{~d} \pm 2.6$ & $122.1 \mathrm{c} \pm 5.6$ \\
$P$. & $0.00^{* *}$ & $0.00^{* *}$ & $0.00^{* *}$ & $0.00^{* *}$ \\
\hline
\end{tabular}

${ }^{*}$ indicate $\mathrm{P}<0.01$. Means followed by a common letter are not significantly different at the $1 \%$ level by DMRT.
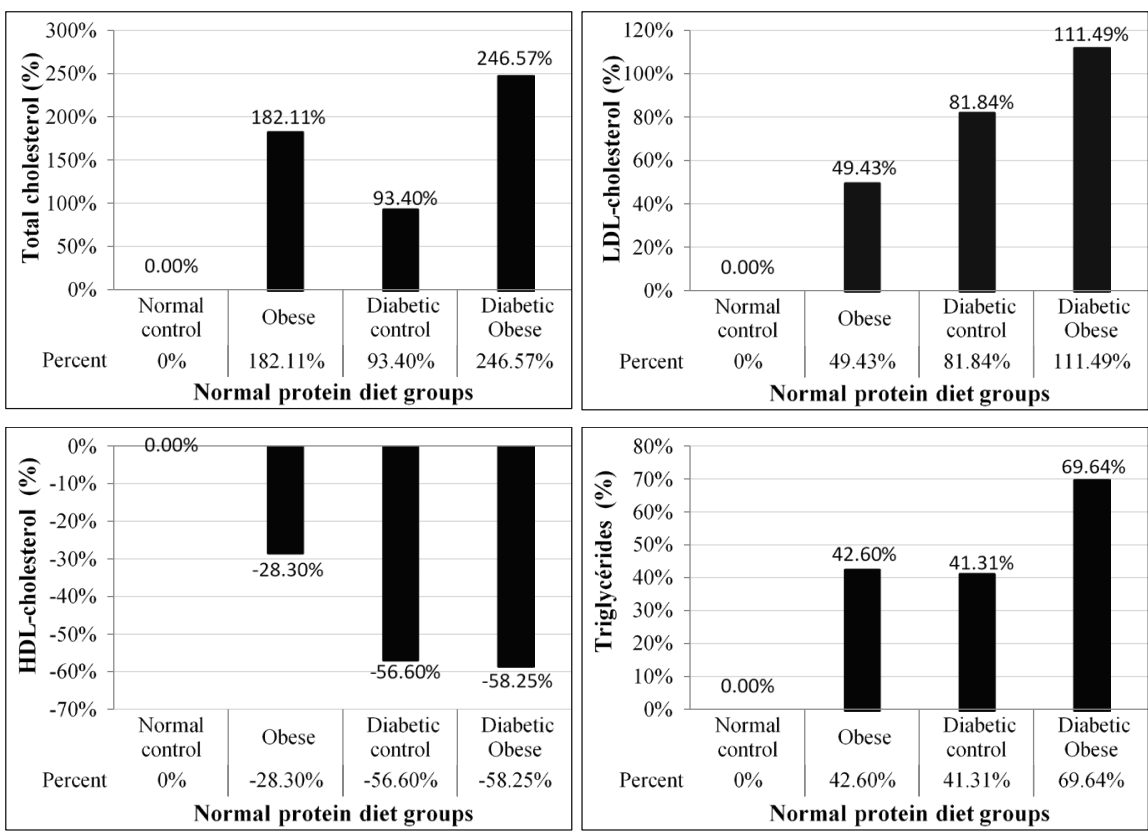

Figure 3. Percentage of total cholesterol, LDL-cholesterol, HDL-cholesterol and triglycerides for different groups received normal protein diet compare to normal control.

Maximum reduction in HDL level in diabetic obese group by (-54.2\%) compare to normal control group.

\subsection{Effect of High Protein Diet on Urea, Creatinine, TP, Albumin and Lactate Dehydrogenase}

As shown in (Table 4), the serum urea, creatinine and total protein in the HP diet groups (G2, G4, G6, G8) animals was observed to be significantly higher (P $<0.01)$ than those in the normal diet groups $(\mathrm{G} 1, \mathrm{G} 3, \mathrm{G} 5, \mathrm{G} 7)$ as shown in (Table 4). 

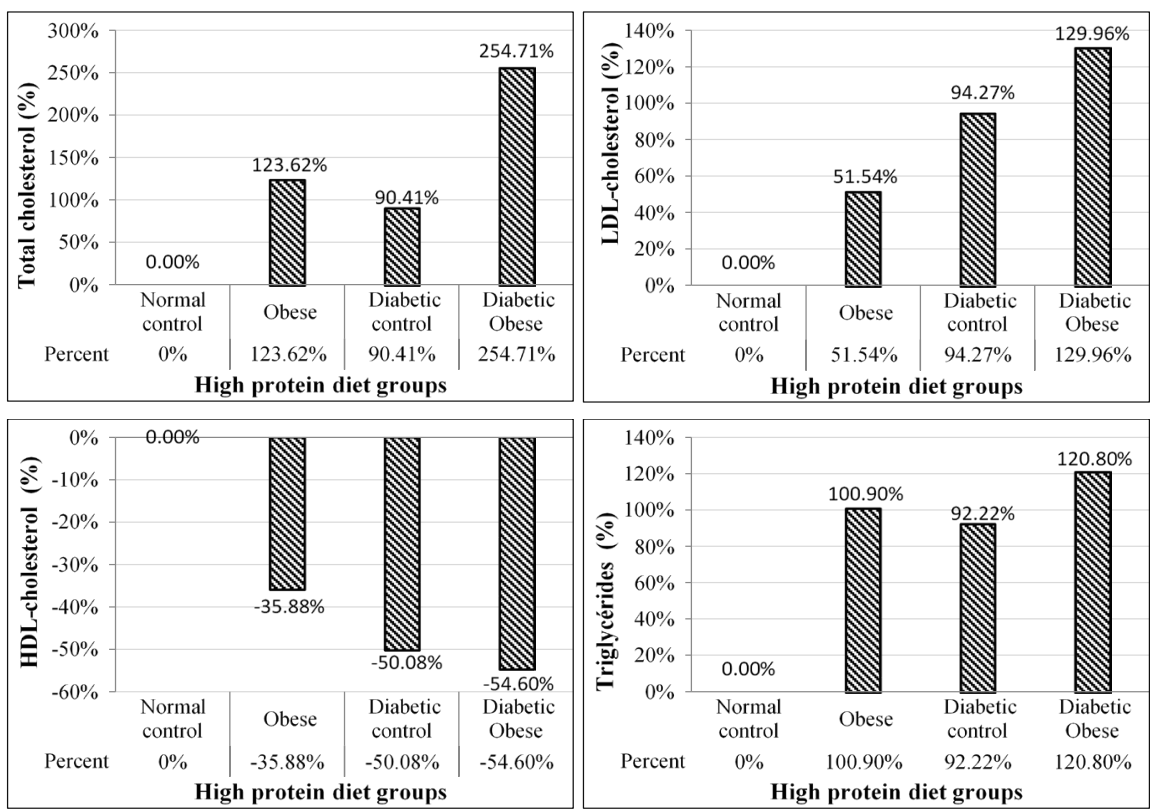

Figure 4. Percentage of total cholesterol, LDL-cholesterol, HDL-cholesterol and triglycerides for different groups received high protein diet compare to normal control.

Table 4. Means \pm (SD) of urea, creatinine, TP, albumin and Lactate Dehydrogenase for all groups.

\begin{tabular}{cccccc}
\hline Groups & Urea $(\mathrm{mg} / \mathrm{dl})$ & $\begin{array}{c}\text { Creatinine } \\
(\mathrm{mg} / \mathrm{dl})\end{array}$ & $\mathrm{TP}(\mathrm{g} / \mathrm{dl})$ & $\begin{array}{c}\text { Albumin } \\
(\mathrm{mg} / \mathrm{dl})\end{array}$ & $\begin{array}{c}\text { Lactate }(\mathrm{u} / \mathrm{L}) \\
\text { Dehydrogenase }\end{array}$ \\
\hline $\mathrm{G} 1$ & $18.9 \mathrm{e} \pm 1.9$ & $0.474 \mathrm{~d} \pm 0.08$ & $4.71 \mathrm{~cd} \pm 0.35$ & $2.56 \mathrm{~b} \pm 0.35$ & $640.8 \mathrm{c} \pm 40.7$ \\
$\mathrm{G} 2$ & $28.8 \mathrm{~d} \pm 1.3$ & $1.26 \mathrm{~b} \pm 0.1$ & $5.69 \mathrm{a} \pm 0.36$ & $2.91 \mathrm{a} \pm 0.27$ & $514.6 \mathrm{e} \pm 18.0$ \\
$\mathrm{G} 3$ & $19.4 \mathrm{e} \pm 2.0$ & $0.352 \mathrm{e} \pm 0.1$ & $4.21 \mathrm{e} \pm 0.28$ & $2.54 \mathrm{~b} \pm 0.27$ & $762.1 \mathrm{~b} \pm 44.4$ \\
$\mathrm{G} 4$ & $32.4 \mathrm{~d} \pm 3.6$ & $1.179 \mathrm{~b} \pm 0.12$ & $4.95 \mathrm{bc} \pm 0.38$ & $2.58 \mathrm{~b} \pm 0.19$ & $593.5 \mathrm{~d} \pm 14.5$ \\
$\mathrm{G} 5$ & $109.1 \mathrm{c} \pm 8.1$ & $1.076 \mathrm{c} \pm 0.09$ & $4.39 \mathrm{de} \pm 0.32$ & $2.41 \mathrm{~b} \pm 0.32$ & $832.4 \mathrm{a} \pm 30.0$ \\
$\mathrm{G} 6$ & $212 \mathrm{a} \pm 6.8$ & $1.51 \mathrm{a} \pm 0.19$ & $5.12 \mathrm{bc} \pm 0.61$ & $2.6 \mathrm{~b} \pm 0.31$ & $743.1 \mathrm{~b} \pm 21.8$ \\
$\mathrm{G} 7$ & $114.3 \mathrm{~b} \pm 9.5$ & $1.001 \mathrm{c} \pm 0.08$ & $4.19 \mathrm{e} \pm 0.22$ & $2.12 \mathrm{c} \pm 0.14$ & $848.9 \mathrm{a} \pm 33.8$ \\
$\mathrm{G} 8$ & $214.6 \mathrm{a} \pm 6.4$ & $1.41 \mathrm{a} \pm 0.08$ & $5.25 \mathrm{~b} \pm 0.73$ & $2.53 \mathrm{~b} \pm 0.33$ & $765.1 \mathrm{~b} \pm 19.4$ \\
$P$. & $0.00^{* *}$ & $0.00^{* *}$ & $0.00^{* *}$ & $0.00^{* *}$ & $0.00^{* *}$ \\
\hline
\end{tabular}

${ }^{*}$ indicate $\mathrm{P}<0.01$. Means followed by a common letter are not significantly different at the $1 \%$ level by DMRT.

The levels of serum Lactate dehydrogenase and albumin was significantly $(\mathrm{P}<$ 0.01) decreased by protein diet treatments in G2, G4, G6 and G8 when compared with G1, G3, G5 and G7 respectively.

Data in Figure 5 showed that urea was increased in diabetic obese rat received normal diet relative to normal control by (504.7\%). Creatinine was maximally increased in diabetic by rats by (127\%). Albumin and TP were maximally reduced in diabetic obese group by $(-11.04 \%)$ and $(-17.19 \%)$ respectively when compare to normal control group. 

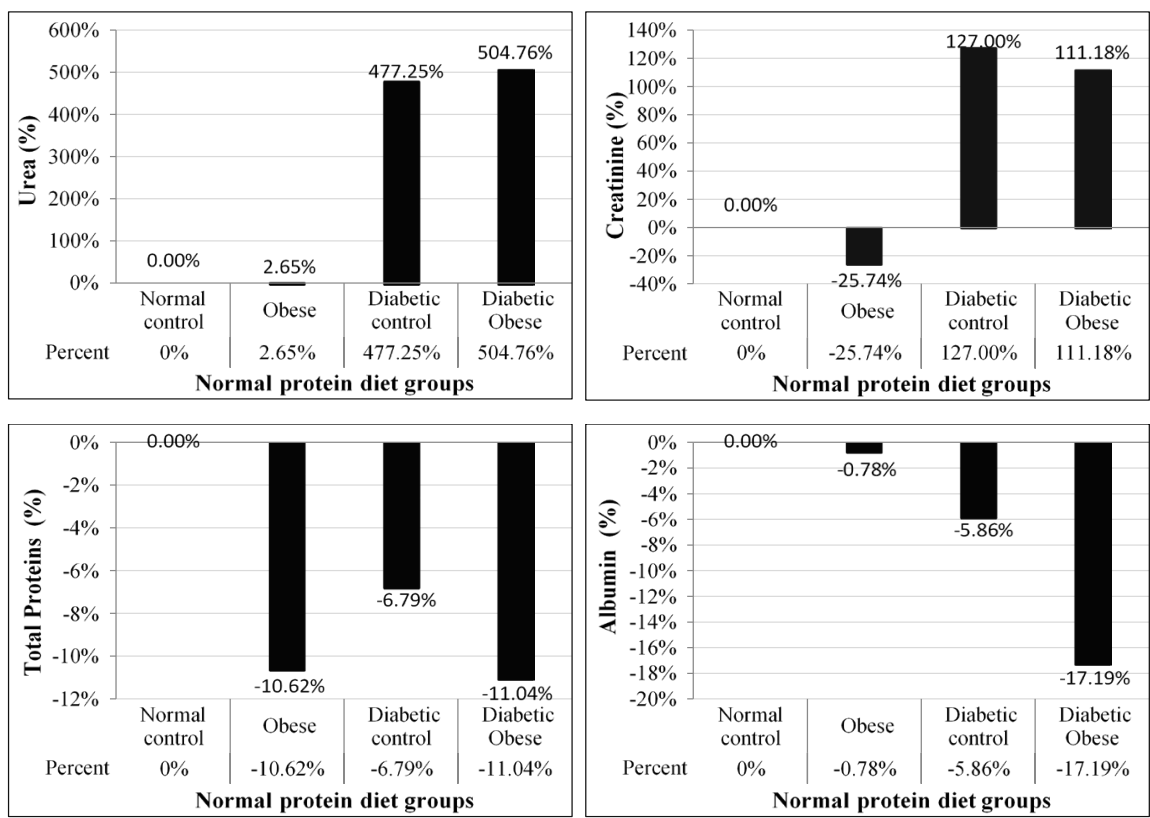

Figure 5. Percentage of urea, creatinine, total proteins and albumin for different groups received normal protein diet compare to normal control.

Data in Figure 6 showed that urea was increased in diabetic obese rat received HP diet relative to normal control by (645.1\%). Creatinine was maximally increased in diabetic by rats by $(19.84 \%)$. Albumin and TP were maximally reduced in diabetic obese group by $(-54.60 \%)$ and $(-13.06 \%)$ respectively when compare to normal control group.

Data in Figure 7 showed that LD was increased in diabetic obese rat received normal diet relative to normal control by $(32.4 \%)$ and in diabetic obese rat received HP diet by (48.68\%).

\subsection{Effect of High Protein Diet Onurine}

In our study, there were increased urine volume and urinary excretion of $\mathrm{Ca}$, with decreased urinary citrate in non-diabetic rats. There was also significant decrease in urine $\mathrm{pH}$ in obese rats received high protein diet as shown in Table 5 .

Data in Figure 8 showed that UV was increased in diabetic obese rat received normal diet relative to normal control by (455\%). Urine $\mathrm{pH}$ was maximally decreased in diabetic obese rats by (v24.8\%). Urine Ca was maximally increased in diabetic control rats by (24.56\%). Urine Citrate was maximally reduced in obese rats by $(-23 \%)$ when compare to normal control group.

Data in Figure 9 showed that UV was increased in diabetic obese rat received HP diet relative to normal control by (190\%). Urine $\mathrm{pH}$ was maximally reduced in diabetic obese rats by $(-15.6 \%)$. Urine Ca was maximally increased in obese control rats by $(2.47 \%)$. Urine Citrate was maximally increased in obese rats by (397.56\%) when compare to normal control group. 

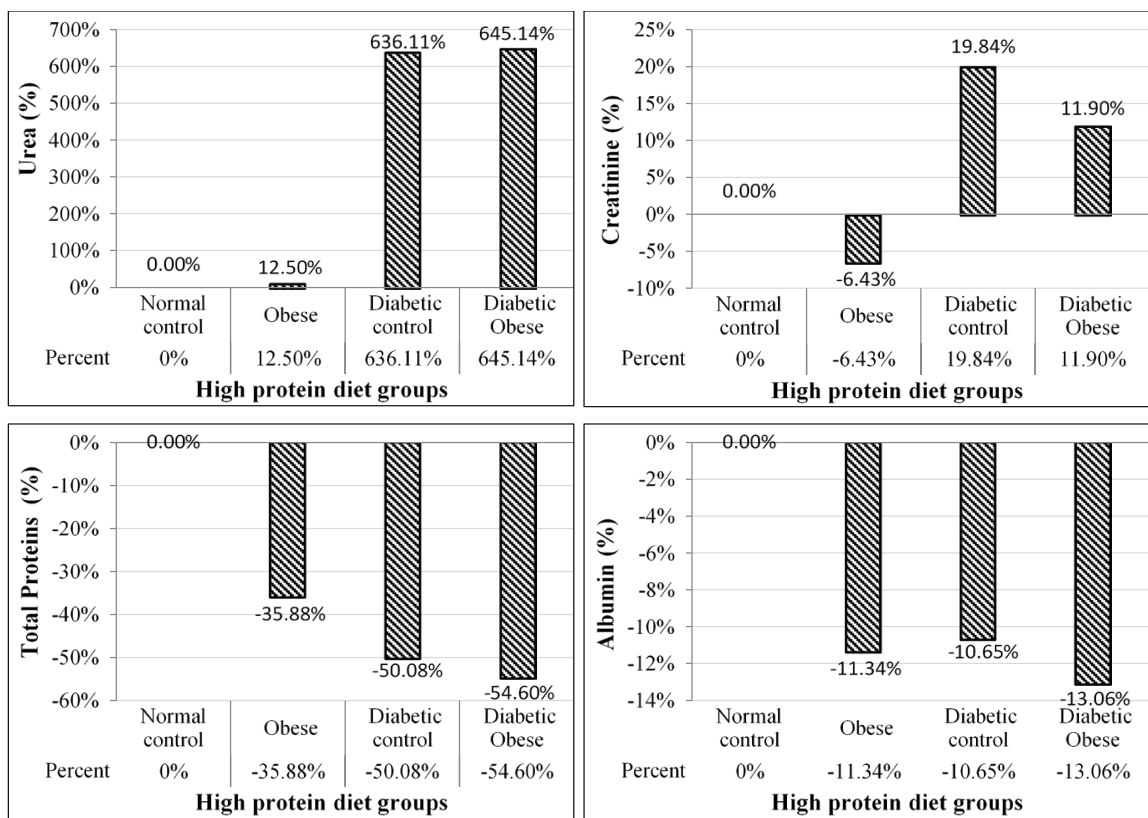

Figure 6. Percentage of urea, creatinine, total proteins and albumin for different groups received high protein diet compare to normal control.
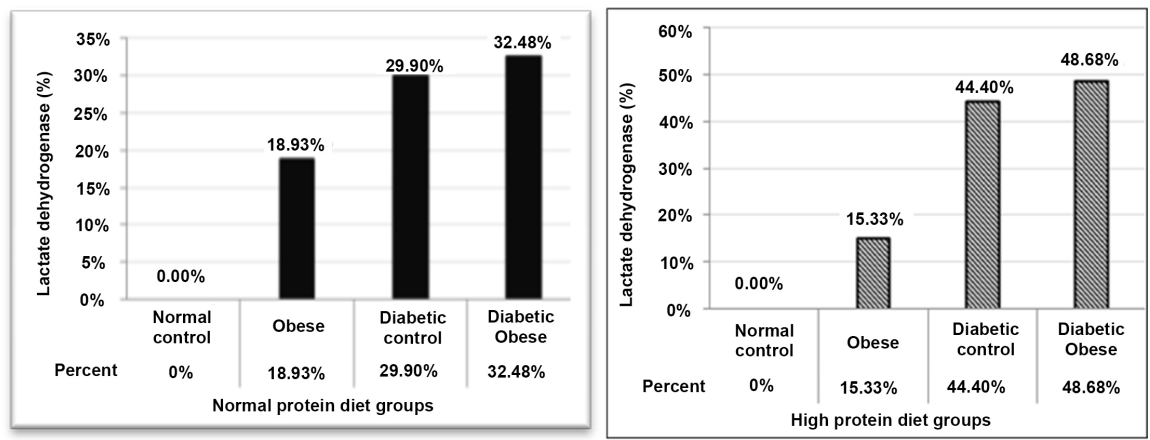

Figure 7. Percentage Lactate dehydrogenase for different groups received normal or high protein diet compare to normal control.

\section{Discussion}

For many years, researches were concerned for management of DM and its predisposing factors. Obesity is the major risk factor for developing T2DM and pare-diabetes [4] [28] [29]. There are many reports in the literature on short-term beneficial effects of high protein diet on BW and BG [4] [30]; However, the risks of using a high-protein diet with carbohydrate limitation for the long term are still being studied especially in high risk groups.

The results of the present study showed that the diet contained $45 \%$ of food as protein received for 12 weeks for normal, obese, diabetic, and diabetic-obese rats lead to significant decrease in BW and FI. The reduction in BW could be a direct result of decreased food intake. Although the differences in food intake could be due to taste and less sucrose content than normal diet. The HP diet reduces hunger and increases feelings of fullness, which result in decreased food intake. 
Table 5. Means $\pm(\mathrm{SD})$ of urine volume, urine $\mathrm{pH}$, urine ca and urine citrate for all groups.

\begin{tabular}{ccccc}
\hline Groups & UV $(\mathrm{ml})$ & U. $\mathrm{pH}$ & $\mathrm{U} . \mathrm{Ca}(\mathrm{mg} /$ day $)$ & U. Citrate $(\mathrm{g} / \mathrm{L})$ \\
\hline G1 & $2.66 \mathrm{f} \pm 0.35$ & $6.73 \mathrm{~b} \pm 1.55$ & $0.509 \mathrm{~d} \pm 0.03$ & $2.895 \mathrm{~b} \pm 0.1$ \\
G2 & $4.01 \mathrm{e} \pm 0.34$ & $6.28 \mathrm{~b} \pm 0.10$ & $0.85 \mathrm{a} \pm 0.06$ & $0.369 \mathrm{~g} \pm 0.07$ \\
G3 & $2.37 \mathrm{f} \pm 0.28$ & $7.64 \mathrm{a} \pm 0.17$ & $0.585 \mathrm{c} \pm 0.03$ & $2.227 \mathrm{~d} \pm 0.07$ \\
G4 & $3.63 \mathrm{e} \pm 0.26$ & $6.26 \mathrm{~b} \pm 0.10$ & $0.871 \mathrm{a} \pm 0.04$ & $1.836 \mathrm{e} \pm 0.14$ \\
G5 & $12.47 \mathrm{~b} \pm 1.06$ & $5.23 \mathrm{~cd} \pm 0.07$ & $0.634 \mathrm{~b} \pm 0.04$ & $3.515 \mathrm{a} \pm 0.08$ \\
G6 & $8.44 \mathrm{~d} \pm 0.65$ & $5.74 \mathrm{c} \pm 0.15$ & $0.86 \mathrm{a} \pm 0.04$ & $1.802 \mathrm{e} \pm 0.11$ \\
G7 & $14.78 \mathrm{a} \pm 0.64$ & $5.06 \mathrm{~d} \pm 0.04$ & $0.6 \mathrm{bc} \pm 0.07$ & $2.37 \mathrm{c} \pm 0.11$ \\
G8 & $11.63 \mathrm{c} \pm 0.85$ & $5.3 \mathrm{~cd} \pm 0.31$ & $0.869 \mathrm{a} \pm 0.05$ & $1.705 \mathrm{f} \pm 0.012$ \\
$P$. & $0.00^{* *}$ & $0.00^{* *}$ & $0.00^{* *}$ & $0.00^{* *}$ \\
\hline
\end{tabular}

**indicate $\mathrm{P}<0.01$. Means followed by a common letter are not significantly different at the $1 \%$ level by DMRT.
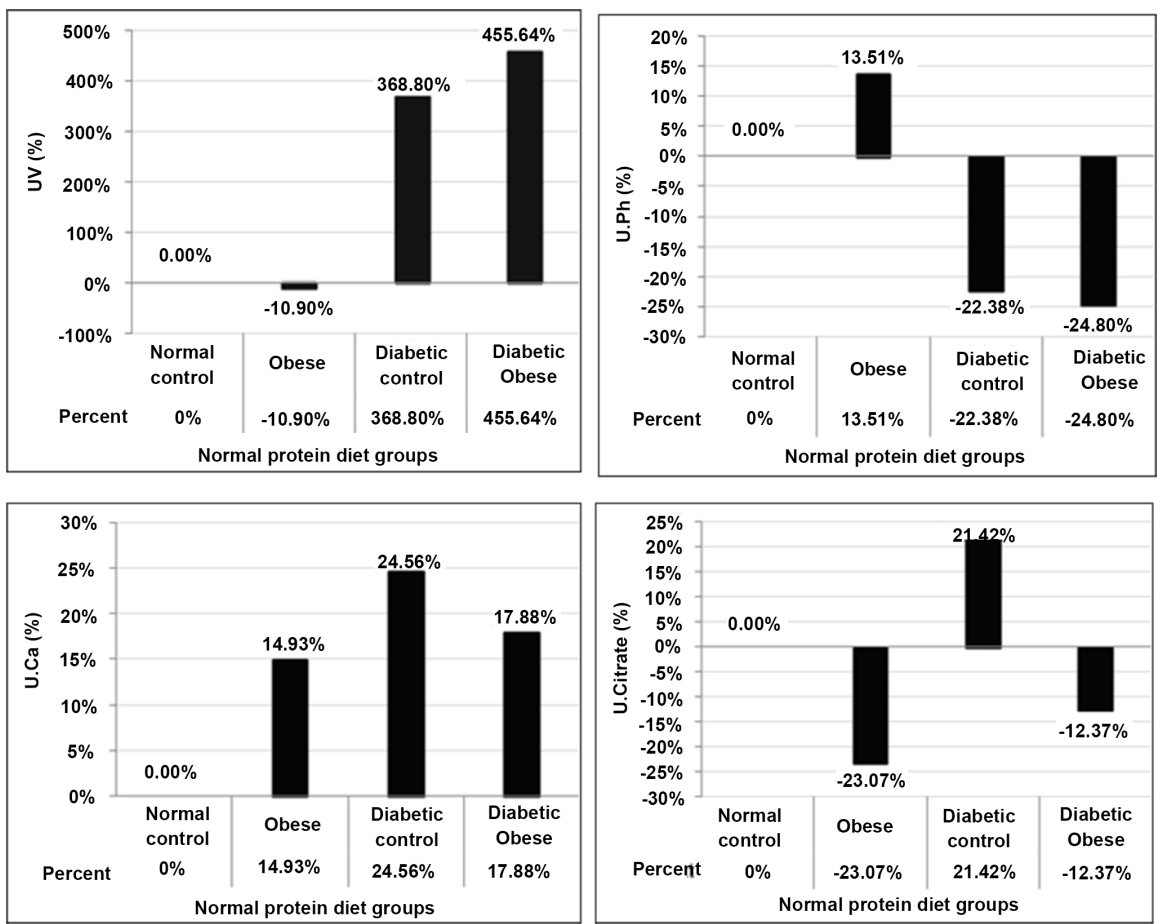

Figure 8. Percentage of UV, U. pH, U. Ca and U. Citrate for different groups received normal protein diet compare to normal control.

Rats fed an HP diet seemed to develop less leptin resistance than rats fed an NP diet, which is in line with their marked reduction of adipose tissue [31] [32]. Our finding was in agreement with previous studies of Farnsworth et al. [5], Layman et al. [33], Lynch and Adams [34], Pesta and Samuel, [10], and French et al. [5].

In the present study, the blood glucose level decreased significantly in high protein diet groups and insulin significantly increased. This decrease in glucose concentrations observed can be explained by decrease FI and the smaller amount 

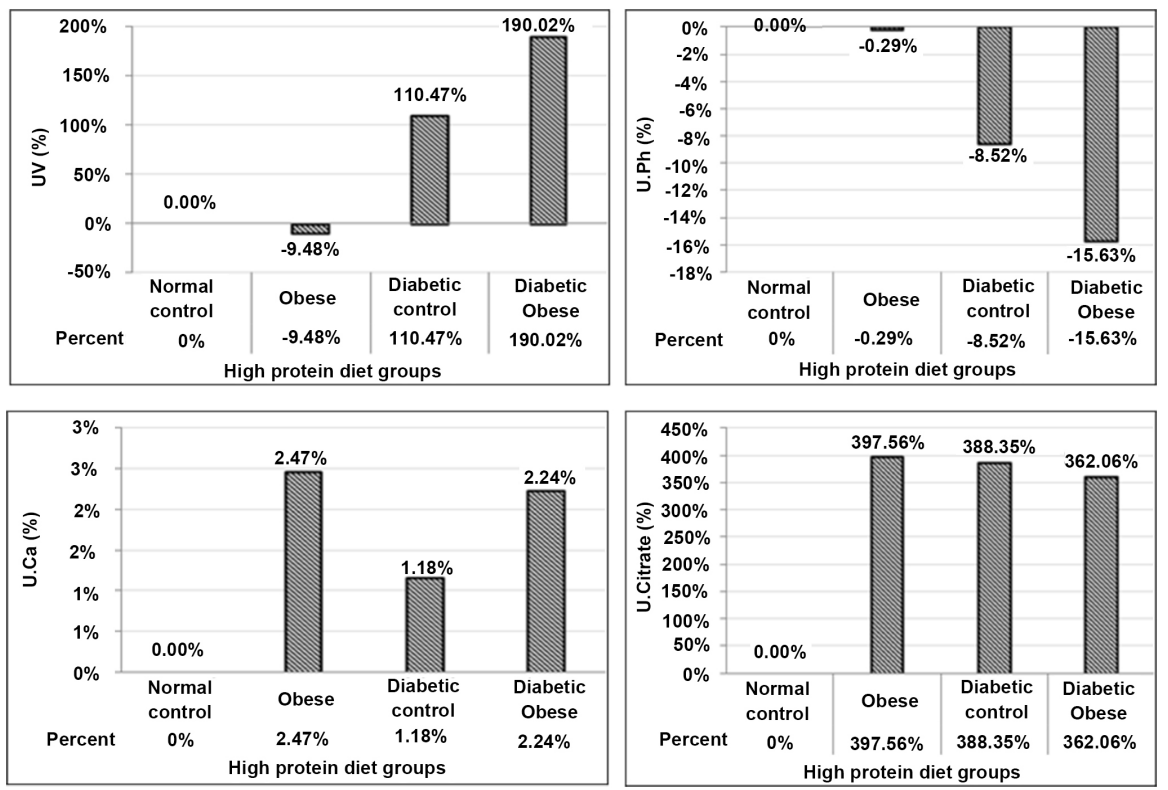

Figure 9. Percentage of UV, U. pH, U. Ca and U. Citrate for different groups received high protein diet compare to normal control.

of carbohydrate in the diet. Thus, the smaller amount of glucose absorbed after meals and also due to a reduced store of glycogen and thus a decrease in glycogenolysis rate. Insulin concentration increased as dietary protein strongly stimulates insulin secretion [35] [36].

The results of the present study showed that there was significant decrease in TC, LDL, TG, while serum HDL was significantly higher in high protein diet groups compared to normal control group. Several studies have reported an improvement in lipid profile levels with high protein diet. However, the findings of the Aparicio et al., [19] showed that HP diet significantly reduced body weight but without clearly improving plasma lipid profile [8] [37] [38] [39].

The results of the present study showed that there was significant decrease in Lactate dehydrogenase, albumin, urine $\mathrm{pH}$ and urine citrate while serum urea, creatinine, total protein, urine volume and urinary excretion of Ca was significantly higher in high protein diet groups. These results were similar to what was found by, Li. [40] \& bin Zaraah et al. [41] \& Hoy. [42]. The levels of serum Lactate dehydrogenase and albumin was significantly decreased by protein diet treatments in cases of malnutrition and/or elevated catabolism and albumin hepatic synthesis can be reduced [43], which explains that the groups HP had lower albumin concentrations than the control group. In our study, there were increased urine volume and urinary excretion of $\mathrm{Ca}$, with decreased urinary citrate in non-diabetic rats. There was also significant decrease in urine $\mathrm{pH}$ in obese rats received high protein diet. Our results is coordinated with the finding of Amanzadeh et al. They found that rats on the high protein diet had much higher urinary volumes and increase in urinary excretion of calcium. They also found that Urinary citrate excretion and urinary $\mathrm{pH}$ was significantly lower were both markedly reduced [44]. In study of Aparicio et al. And bin Zaraah, et al. The HP 
diet increased urinary excretion of $\mathrm{Ca}$ and strongly decreased urinary $\mathrm{pH}$ and citrate and there was increasing in 24-hour urine output in the experimental rats [19] [41]. Hostetter. Stated that dietary protein has an effect to increase the level of GFR of the kidneys and this explain the increase in urine volume [45]. GFR has also been shown to increase by $20 \%-30 \%$ within 1 hour of consuming a high protein meal and that if this were to stimulate urine output [46].

Our result indicated that the high protein induced diminutions in renal function. Despite the metabolic advantages of HP diet, the long-term HP consumption may lead to the development of end stage renal disease (ESRD) said by Malhotra et al. [47]. This finding were supported by the studies of Martin et al [48], Kurpińska and Skrzypczak. \& Hammond and Janes. [49].

On the other hand, Lacroix et al. studied the effects of a diet containing 50\% protein on renal function in Wistar rats and did not observed abnormalities in renal function or pathology [7] [50]. Similarly, Collins et al. 1990, also reported no adverse effects of long-term consumption of high protein diets on renal function in rats [50]. However, some recent studies have shown a positive correlation between high protein intake and ESRD [51] [52]. A protective role for low protein diet has been suggested in patients with diabetic kidney disease; but no nutritional recommendations are made for individuals who are obese, or pre-diabetic [5].

Malhotra et al. observed that, with HP diet there was decline in an estimated glomerular filtration rate (eGFR) among those with diabetes and preserved baseline kidney function, while there was no association was observed between amount of protein intake and eGFR decline among participants without diabetes [47].

The study of Malhotra et al. among black men and women with a high burden of risk factors for kidney disease, they have demonstrated that higher protein intake was associated with ESRD, a finding consistent with metabolic studies suggesting that diabetes and obesity (which are common among blacks) alter protein metabolism [53].

Our finding can be explaned by hyperfiltration that caused by HP leading to subsequent renal damage, as postulated by Brenner et al., [47] [54]. It may also be possible that by-products of excess protein metabolism could cause injury to podocytes and other kidney cells resulting in impaired kidney function and subsequent ESRD [53].

\section{Conclusion}

In conclusion, a high protein intake in albino rats fed for 12 weeks showed changes in the serum and urine levels of markers of renal function which indicate abnormalities in the function of the kidney especially in diabetic and pare-diabetic groups.

\section{Conflicts of Interest}

The authors declare that they have no competing interest. 


\section{Financial Support}

This study was funded by Department of physiology, Faculty of Medicine, Al-Azhar University, Assuit, Egypt. without any particular role in the study design, recruitment of individuals, data analysis or writing of the report.

\section{Author's Contributions}

Nour El-Deen A. and Mansour A. involved in the study concept , design and recruitment of animal, induction of diabetes, obesity and follow up, and contributed to data acquisition; Taha A performed the biochemical tests; Nour El-Deen A. and Taha A. performed statistical analysis and designed the figures; Nour El-Deen A. and Mansour A. performed data interpretation; Mansour A., Nour El-Deen A., and Taha A. wrote the manuscript; all the authors reviewed the manuscript and finally approved it for submission.

\section{References}

[1] Morales, F.E., Tinsley, G.M. and Gordon, P.M. (2017) Acute and Long-Term Impact of High-Protein Diets on Endocrine and Metabolic Function, Body Composition, and Exercise-Induced Adaptations. Journal of the American College of Nutrition, 36, 295-305. https://doi.org/10.1080/07315724.2016.1274691

[2] Kranz, S., et al. (2017) High-Protein and High-Dietary Fiber Breakfasts Result in Equal Feelings of Fullness and Better Diet Quality in Low-Income Preschoolers Compared with Their Usual Breakfast-3. The Journal of Nutrition, 147, 445-452.

[3] Snorgaard, O., et al. (2017) Systematic Review and Meta-Analysis of Dietary Carbohydrate Restriction in Patients with Type 2 Diabetes. BMJ Open Diabetes Research and Care, 5, e000354. https://doi.org/10.1136/bmjdrc-2016-000354

[4] Halton, T.L. and Hu, F.B. (2004) The Effects of High Protein Diets on Thermogenesis, Satiety and Weight Loss: A Critical Review. Journal of the American College of Nutrition, 23, 373-385. https://doi.org/10.1080/07315724.2004.10719381

[5] French, W.W., et al. (2017) A High-Protein Diet Reduces Weight Gain, Decreases Food Intake, Decreases Liver Fat Deposition, and Improves Markers of Muscle Metabolism in Obese Zucker Rats. Nutrients, 9, 587.

https://doi.org/10.3390/nu9060587

[6] Mangano, K.M., Sahni, S., Kiel, D.P., Tucker, K.L., Dufour, A.B. and Hannan, M.T. (2017) Dietary Protein Is Associated with Musculoskeletal Health Independently of Dietary Pattern: The Framingham Third Generation Study, 2. The American Journal of Clinical Nutrition, 105, 714-722.

[7] Lacroix, M., et al. (2004) A Long-Term High-Protein Diet Markedly Reduces Adipose Tissue without Major Side Effects in Wistar Male Rats. American Journal of Physiology-Regulatory, Integrative and Comparative Physiology, 287, R934-R942. https://doi.org/10.1152/ajpregu.00100.2004

[8] Marques, F.Z., Nelson, E., Chu, P.Y., Horlock, D., Fiedler, A., Ziemann, M., et al. (2017) High-Fiber Diet and Acetate Supplementation Change the Gut Microbiota and Prevent the Development of Hypertension and Heart Failure in Hypertensive Miceclinical Perspective. Circulation, 135, 964-977.

[9] Kostogrys, R.B., et al. (2015) Effect of Low Carbohydrate High Protein (LCHP) Diet on Lipid Metabolism, Liver and Kidney Function in Rats. Environmental Toxicolo- 
gy and Pharmacology, 39, 713-719. https://doi.org/10.1016/j.etap.2015.01.008

[10] Pesta, D.H. and Samuel, V.T. (2014) A High-Protein Diet for Reducing Body Fat: Mechanisms and Possible Caveats. Nutrition \& Metabolism, 11, 53. https://doi.org/10.1186/1743-7075-11-53

[11] Park, S., et al. (2017) Intermittent Fasting Reduces Body Fat But Exacerbates Hepatic Insulin Resistance in Young Rats Regardless of High Protein and Fat Diets. The Journal of Nutritional Biochemistry, 40, 14-22. https://doi.org/10.1016/j.jnutbio.2016.10.003

[12] Beaumont, M., et al. (2017) Epithelial Response to a High-Protein Diet in Rat Colon. BMC Genomics, 18, 116. https://doi.org/10.1186/s12864-017-3514-Z

[13] Barham, D. and Trinder, P. (1972) An Improved Colour Reagent for the Determination of Blood Glucose by the Oxidase System. Analyst, 97, 142-145. https://doi.org/10.1039/an9729700142

[14] Lequin, R.M. (2005) Enzyme Immunoassay (EIA)/Enzyme-Linked Immunosorbent Assay (ELISA). Clinical Chemistry, 51, 2415-2418. https://doi.org/10.1373/clinchem.2005.051532

[15] Ellefson, R. and Caraway, W. (1976) Lipids and Lipoproteins. In: Fundamentals of Clinical Chemistry, WB Saunders Philadelphia, 474-542.

[16] Bucolo, G. and David, H. (1973) Quantitative Determination of Serum Triglycerides by the Use of Enzymes. Clinical Chemistry, 19, 476-482.

[17] Patton, G. and Crouch, S. (1977) Colorimetric Method for the Determination of Serum Urea. Analytical Chemistry, 49, 464-469. https://doi.org/10.1021/ac50011a034

[18] Lustgarten, J.A. and Wenk, R.E. (1972) Simple, Rapid, Kinetic Method for Serum Creatinine Measurement. Clinical Chemistry, 18, 1419-1422.

[19] Gulati, S., Misra, A., Tiwari, R., Sharma, M., Pandey, R.M. and Yadav, C.P. (2017) Effect of High-Protein Meal Replacement on Weight and Cardiometabolic Profile in Overweight/Obese Asian Indians in North India. British Journal of Nutrition, 117, 1531-1540.

[20] Aparicio, V., et al. (2013) Dietas hiperproteicas y estado renal en ratas. Nutrición Hospitalaria, 28, 232-237.

[21] Kurien, B.T. and Scofield, R.H. (1999) Mouse Urine Collection Using Clear Plastic Wrap. Laboratory Animals, 33, 83-86. https://doi.org/10.1258/002367799780578525

[22] Mahmoud, A.M., Ashour, M.B., Abdel-Moneim, A. and Ahmed, O.M. (2012) Hesperidin and Naringin Attenuate Hyperglycemia-Mediated Oxidative Stress and Proinflammatory Cytokine Production in High Fat Fed/Streptozotocin-Induced Type 2 Diabetic Rats. Journal of Diabetes and Its Complications, 26, 483-490. https://doi.org/10.1016/j.jdiacomp.2012.06.001

[23] Saddala, R.R., Thopireddy, L., Ganapathi, N. and Kesireddy, S.R. (2013) Regulation of Cardiac Oxidative Stress and Lipid Peroxidation in Streptozotocin-Induced Diabetic Rats Treated with Aqueous Extract of Pimpinella tirupatiensis Tuberous Root. Experimental and Toxicologic Pathology, 65, 15-19. https://doi.org/10.1016/j.etp.2011.05.003

[24] Rothwell, N.J. and Stock, M.J. (1981) Influence of Noradrenaline on Blood Flow to Brown Adipose Tissue in Rats Exhibiting Diet-Induced Thermogenesis. Pflügers Archiv European Journal of Physiology, 389, 237-242. https://doi.org/10.1007/BF00584784

[25] Novelli, E., et al. (2007) Anthropometrical Parameters and Markers of Obesity in 
Rats. Laboratory Animals, 41, 111-119. https://doi.org/10.1258/002367707779399518

[26] Reeves, P.G., Nielsen, F.H. and Fahey Jr., G.C. (1993) AIN-93 Purified Diets for Laboratory Rodents: Final Report of the American Institute of Nutrition ad hoc Writing Committee on the Reformulation of the AIN-76A Rodent Diet. Oxford University Press, Oxford.

[27] Duncan, O.D. and Duncan, B. (1955) A Methodological Analysis of Segregation Indexes. American Sociological Review, 20, 210-217. https://doi.org/10.2307/2088328

[28] Ambareesha, K., Nagadeepa, W. and Suresh, M. (2017) Obesity as Risk Factor in Type-2 Diabetes Mellitus in Middle Aged Women. International Journal of Current Research in Physiology and Pharmacology, 1, 6-9.

[29] American Diabetes Association (2017) 2. Classification and Diagnosis of Diabetes. Diabetes Care, 40, S11-S24. https://doi.org/10.2337/dc17-S005

[30] Anderson, G.H. and Moore, S.E. (2004) Dietary Proteins in the Regulation of Food Intake and Body Weight in Humans. The Journal of Nutrition, 134, 974S-979S. https://doi.org/10.1093/jn/134.4.974S

[31] Du, F., Higginbotham, D.A. and White, B.D. (2000) Food Intake, Energy Balance and Serum Leptin Concentrations in Rats Fed Low-Protein Diets. The Journal of Nutrition, 130, 514-521. https://doi.org/10.1093/jn/130.3.514

[32] Havel, P.J. (2000) Role of Adipose Tissue in Body-Weight Regulation: Mechanisms Regulating Leptin Production and Energy Balance. Proceedings of the Nutrition Society, 59, 359-371. https://doi.org/10.1017/S0029665100000410

[33] Layman, D.K., et al. (2003) A Reduced Ratio of Dietary Carbohydrate to Protein Improves Body Composition and Blood Lipid Profiles during Weight Loss in Adult Women. The Journal of Nutrition, 133, 411-417. https://doi.org/10.1093/jn/133.2.411

[34] Lynch, C.J. and Adams, S.H. (2014) Branched-Chain Amino Acids in Metabolic Signalling and Insulin Resistance. Nature Reviews Endocrinology, 10, 723. https://doi.org/10.1038/nrendo.2014.171

[35] Gannon, M.C. and Nuttall, F.Q. (2004) Effect of a High-Protein, Low-Carbohydrate Diet on Blood Glucose Control in People with Type 2 Diabetes. Diabetes, 53, 2375-2382. https://doi.org/10.2337/diabetes.53.9.2375

[36] Pasiakos, S.M., Lieberman, H.R. and Fulgoni, I.I.I.V.L. (2015) Higher-Protein Diets Are Associated with Higher HDL Cholesterol and Lower BMI and Waist Circumference in US Adults. The Journal of Nutrition, 145, 605-614. https://doi.org/10.3945/jn.114.205203

[37] Volek, J.S. and Feinman, R.D. (2005) Carbohydrate Restriction Improves the Features of Metabolic Syndrome. Metabolic Syndrome May Be Defined by the Response to Carbohydrate Restriction. Nutrition \& Metabolism, 2, 31. https://doi.org/10.1186/1743-7075-2-31

[38] Evangelista, L.S., Heber, D., Li, Z., Bowerman, S., Hamilton, M.A. and Fonarow, G.C. (2009) Reduced Body Weight and Adiposity with a High-Protein Diet Improves Functional Status, Lipid Profiles, Glycemic Control, and Quality of Life in Patients with Heart Failure: A Feasibility Study. The Journal of Cardiovascular Nursing, 24, 207-215. https://doi.org/10.1097/JCN.0b013e31819846b9

[39] Amini, P., Maghsoudi, Z., Feizi, A., Ghiasvand, R. and Askari, G. (2016) Effects of High Protein and Balanced Diets on Lipid Profiles and Inflammation Biomarkers in Obese and Overweight Women at Aerobic Clubs: A Randomized Clinical Trial. In- 
ternational Journal of Preventive Medicine, 7, 110.

https://doi.org/10.4103/2008-7802.190608

[40] Li, L., et al. (2015) A Long-Term High-Fat/High-Sucrose Diet Promotes Kidney Lipid Deposition and Causes Apoptosis and Glomerular Hypertrophy in Bama Minipigs. PLOS ONE, 10, e0142884. https://doi.org/10.1371/journal.pone.0142884

[41] Zaraah, A.B., et al. (2013) The Effect of High Casein Diet on the Histology and Function of Rat Kidney. International Journal of Health Sciences \& Research, 3, 1-12. http://www.ijhsr.org

[42] Hoy, W.E., Bertram, J.F., Denton, R.D., Zimanyi, M., Samuel, T. and Hughson, M.D. (2008) Nephron Number, Glomerular Volume, Renal Disease and Hypertension. Current Opinion in Nephrology and Hypertension, 17, 258-265. https://doi.org/10.1097/MNH.0b013e3282f9b1a5

[43] Mkhize, P.B. (2016) A Comparison of the Efficacy of Syzygium Jambolanum (Java Plum) $6 \mathrm{CH}$ and Syzygium Jambolanum (Java Plum) Homoeopathic Mother Tincture in the Treatment of Type 2 Diabetes Mellitus in Patients on Metformin?

[44] Amanzadeh, J., et al. (2003) Effect of High Protein Diet on Stone-Forming Propensity and Bone Loss in Rats. Kidney International, 64, 2142-2149.

https://doi.org/10.1046/j.1523-1755.2003.00309.x

[45] Hostetter, T.H., Meyer, T.W., Rennke, H.G. and Brenner, B.M. (1986) Chronic Effects of Dietary Protein in the Rat with Intact and Reduced Renal Mass. Kidney International, 30, 509-517. https://doi.org/10.1038/ki.1986.215

[46] Bosch, J.P., Saccaggi, A., Lauer, A., Ronco, C., Belledonne, M. and Glabman, S. (1983) Renal Functional Reserve in Humans: Effect of Protein Intake on Glomerular Filtration Rate. The American Journal of Medicine, 75, 943-950. https://doi.org/10.1016/0002-9343(83)90873-2

[47] Malhotra, R., et al. (2018) Protein Intake and Long-Term Change in Glomerular Filtration Rate in the Jackson Heart Study. Journal of Renal Nutrition, 28, 245-250. https://doi.org/10.1053/j.jrn.2017.11.008

[48] Martin, W.F., Armstrong, L.E. and Rodriguez, N.R. (2005) Dietary Protein Intake and Renal Function. Nutrition \& Metabolism, 2, 25. https://doi.org/10.1186/1743-7075-2-25

[49] Hammond, K.A. and Janes, D.N. (1998) The Effects of Increased Protein Intake on Kidney Size and Function. The Journal of Experimental Biology, 201, 2081-2090.

[50] Friedman, A.N. (2004) High-Protein Diets: Potential Effects on the Kidney in Renal Health and Disease. American Journal of Kidney Diseases, 44, 950-962. https://doi.org/10.1053/j.ajkd.2004.08.020

[51] Baum, J.I., O’Connor, J.C., Seyler, J.E., Anthony, T.G., Freund, G.G. and Layman, D.K. (2005) Leucine Reduces the Duration of Insulin-Induced PI 3-Kinase Activity in Rat Skeletal Muscle. American Journal of Physiology-Endocrinology and Metabolism, 288, E86-E91. https://doi.org/10.1152/ajpendo.00272.2004

[52] Lassiter, K., et al. (2015) Orexin System Is Expressed in Avian Muscle Cells and Regulates Mitochondrial Dynamics. American Journal of Physiology-Regulatory, Integrative and Comparative Physiology, 308, R173-R187. https://doi.org/10.1152/ajpregu.00394.2014

[53] Abbate, M., Zoja, C. and Remuzzi, G. (2006) How Does Proteinuria Cause Progressive Renal Damage? Journal of the American Society of Nephrology, 17, 2974-2984.

[54] Malhotra, R., Cavanaugh, K.L., Blot, W.J., Ikizler, T.A., Lipworth, L. and Kabagambe, E.K. (2016) Higher Protein Intake Is Associated with Increased Risk for In- 
cident End-Stage Renal Disease among Blacks with Diabetes in the Southern Community Cohort Study. Nutrition, Metabolism and Cardiovascular Diseases, 26, 1079-1087. https://doi.org/10.1016/j.numecd.2016.07.009 